Article

\title{
Synthesis and Bioactivity Evaluation of New 6-Aryl-5-cyano Thiouracils as Potential Antimicrobial and Anticancer Agents
}

\section{Azza Taher Taher ${ }^{1}$ and Sahar Mahmoud Abou-Seri ${ }^{2, *}$}

1 Department of Pharmaceutical Organic Chemistry, Faculty of Pharmacy, Cairo University, Kasr El-Aini Street, Cairo, P.O. Box, 11562, Egypt; E-Mail: azzataher2005@yahoo.com Department of Pharmaceutical Chemistry, Faculty of Pharmacy, Cairo University, Kasr El-Aini Street, Cairo, P.O. Box, 11562, Egypt

* Author to whom correspondence should be addressed; E-Mail: saharshaarawy_69@yahoo.com; Tel.: +20-2-2559-1683; Fax: +20-2-2362-8426.

Received: 16 July 2012; in revised form: 25 July 2012 / Accepted: 10 August 2012 /

Published: 17 August 2012

\begin{abstract}
Several novel 6-aryl-5-cyano thiouracil derivatives were synthesized and explored for their activities as antibacterial, antifungal and anticancer agents. The antimicrobial evaluation revealed that compounds $\mathbf{7 b}$ and $\mathbf{7 c}$ possessed superior antibacterial activity against the Gram positive bacteria $S$. aureus and B. subtilis compared to the reference drug amoxicillin. Moreover, compound $4 \mathbf{i}$ was found to be a broad spectrum antimicrobial agent and it also exhibited the highest antifungal activity against C. albicans, even higher than the reference drug amphotericin B (MIC $=2.34,3.00 \mu \mathrm{g} / \mathrm{mL}$ respectively). Selected compounds were tested for in vitro cytotoxicity at a single $10^{-5} \mathrm{M}$ concentration in accordance to the NCI (USA) protocol. The preliminary screening results showed that most of the compounds had limited cytotoxic activity against renal cancer UO-31 and/or A498 cell lines. Nevertheless, compounds 6d and 6i displayed potent growth inhibitory effect toward non-small cell lung cancer HOP-92 and leukemia MOLT-4 cell lines, respectively.
\end{abstract}

Keywords: 6-aryl-5-cyano thiouracils; antibacterial; antifungal; anticancer 


\section{Introduction}

Pyrimidines are an important component of nucleic acids and they have been used as building blocks in pharmaceuticals for the synthesis of antiviral [1], antineoplastic [2] antibacterial and antifungal [3] agents. Similarly, the related thiouracil derivatives are potential therapeutics as antiviral, anticancer and antimicrobial agents [4-6]. For example, $S$-alkylation and $\mathrm{N}$-alkylation products have been recently reported as novel antibacterial, cytotoxic agents [7,8] and unique HIV reverse transcriptase inhibitors $[9,10]$. Moreover, a literature survey revealed that the thiouracilcarbonitrile ring system has occupied a marked position in the design and synthesis of novel chemotherapeutic agents with remarkable antitumor and antimicrobial activities (Figure 1). In particular, 2-[(1Hbenzoimidazol-2-yl)methylthio]-4-hydroxy-6-phenylpyrimidine-5-carbonitrile (I) possessed significant broad spectrum antiproliferative activity in vitro [11]. In addition, thiouracil quinoxaline hybrids II demonstrated strong inhibitory effects on the EBV-EA activation with chemopreventive effect against carcinogenesis on Raji cells [12]. On the other hand, the nitrofuran analog III displayed a distinctive inhibitory activity against a panel of Gram positive bacteria [13]. Meanwhile, an array of 4-anilinoand 4-hydrazinothiopyrimidine-5-carbonitriles and their condensed heterocycles exerted promising chemotherapeutic activity as antimicrobial and anticancer agents [14-16]. Also, it was of great interest that specifically functionalized $S$-aralkylated 6-aryl-5-cyano-2-thiouracils may possess specific biological properties, including inhibition of bacterial protein translocase SecA (compound IV) [17], hepatitis C viral NS5B RNA dependent RNA polymerase (compound V) [18] and potent antagonist of Epac protein - a therapeutic target of cancer-(compound VI) [19].

Figure 1. Structures of some potent antimicrobial and anticancer 6-aryl-5-cyano-2-thiouracil lead compounds.

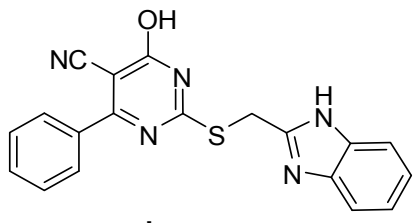

I<smiles>[R]c1ccc(-c2nc(Sc3nc4ccccc4nc3Cl)[nH]c(=O)c2C#N)cc1</smiles>

II

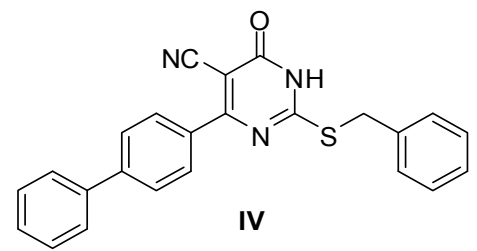

Sec A inhibiror<smiles>N#Cc1c(-c2ccc(Br)cc2)nc(SCc2ccccc2)[nH]c1=O</smiles>

$\mathbf{v}$

NS5B RNA-dependent RNA polymerase inhibitor

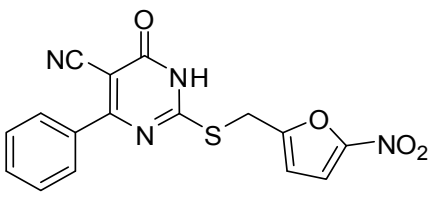

III

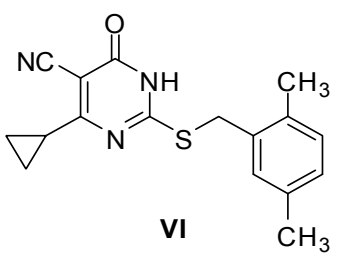

Epac antagonist

In view of the biological significance of the above mentioned thiouracils, we herein report the synthesis and biological evaluation of novel 6-aryl-5-cyano-2-thiouracil derivatives $\mathbf{6 a - i}$ and $7 \mathbf{a}-\mathbf{c}$ as potential antimicrobial and cytotoxic agents. The design of the target compounds $\mathbf{6 a}-\mathbf{i}$ was based on previous report that, for a series of 5-substituted-2-anilinopyrimidinones, a systematic increase in antimicrobial potency was observed upon elongation of the alkyl spacer between the phenyl ring and pyrimidinone pharmacophore from one to three carbons [20]. In analogy to this strategy, a new series 
of thiouracil-5-carbonitile derivatives $\mathbf{6 a - i}$ was prepared in which structure modification was focused on changing the aryl methyl moiety in lead compounds I, II and IV to a bromobenzoylmethyl moiety and simultaneously introducing various substituted aryl groups at the 6 position of the thiouracil ring. The substituent on the aryl group was selected so as to confer different lipophilic and electronic environments on the molecules.

Furthermore, utilizing the active methylene site in $\mathbf{6}$ for incorporation of additional pharmacophoric group, the 4-hydroxyphenylhydrazono derivatives 7a-c were prepared. Hydrazones represents an important class of compounds that show, besides broad spectrum antitumor activity, distinguished antifungal and antibacterial effects [21,22].

\section{Results and Discussion}

\subsection{Chemistry}

The synthetic approaches adopted to obtain the target compounds 6-9 are depicted in Schemes 1 and 2. The structures of the newly synthesized compounds were established on the basis of their elemental analyses and spectral data.

Scheme 1. Synthetic pathway for target compounds $4 \mathbf{a}-\mathbf{i}$ and $\mathbf{6 a}-\mathbf{i}$.
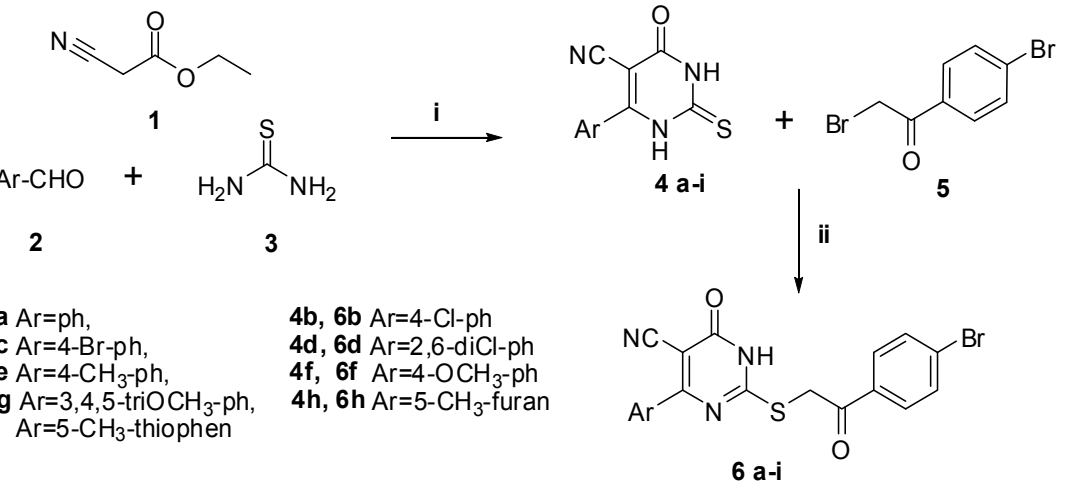

Reagents and conditions: (i) anhydrous $\mathrm{K}_{2} \mathrm{CO}_{3}$, absolute ethanol, reflux $12 \mathrm{~h}$; (ii) anhydrous $\mathrm{K}_{2} \mathrm{CO}_{3}$, dry benzen, reflux, $24 \mathrm{~h}$.

Scheme 2. Synthetic pathways for compounds $7 \mathbf{a}-\mathbf{c}$ and 9.

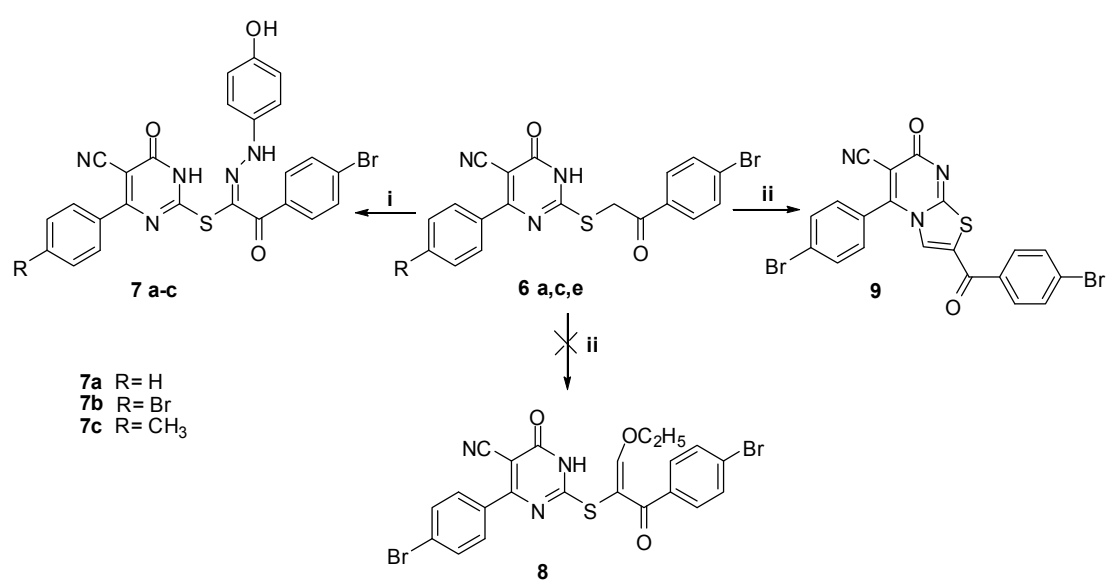

Reagents and conditions: (i) $p$-aminophenol, glacial acetic acid, $\mathrm{NaNO}_{2}$, stir at $-5{ }^{\circ} \mathrm{C}, 30 \mathrm{~min}$. (ii) $\left(\mathrm{C}_{2} \mathrm{H}_{5} \mathrm{O}\right)_{3} \mathrm{CH}$, acetic anhydride, reflux, $8 \mathrm{~h}$. 
Ternary condensation of ethyl cyanoacetate $\mathbf{1}$ with the appropriate aldehyde $\mathbf{2}$ and thiourea $\mathbf{3}$ in the presence of anhydrous potassium carbonate afforded the 6-aryl-4-oxo-2-thioxo-1,2,3,4-tetrahydropyrimidine-5-carbonitrile (thiouracils) 4a-i. The IR spectra of these compounds were characterized by the presence of NH stretching bands at $3410-3124 \mathrm{~cm}^{-1}, \mathrm{C} \equiv \mathrm{N}$ bands at $2214-2152 \mathrm{~cm}^{-1}$ along with $\mathrm{C}=\mathrm{O}$ bands at $1652-1625 \mathrm{~cm}^{-1}$ and $\mathrm{C}=\mathrm{S}$ bands at $1253-1222 \mathrm{~cm}^{-1}$.

Selective $S$-alkylation of $\mathbf{4 a - i}$ with bromophenacyl bromide 5 to produce compounds $\mathbf{6 a}-\mathbf{i}$ was carried out in refluxing dry benzene utilizing potassium carbonate as base catalyst (Scheme 1). The IR spectral data of compounds $\mathbf{6 a}-\mathbf{i}$ displayed no absorption bands for $\mathrm{C}=\mathrm{S}$, while an additional benzoyl $\mathrm{C}=\mathrm{O}$ band was observed at $1735-1693 \mathrm{~cm}^{-1}$. Their ${ }^{1} \mathrm{H}-\mathrm{NMR}$ spectra revealed a singlet signal resonating at 5.98-4.51 ppm assignable to $\mathrm{SCH}_{2}$. Compounds $\mathbf{6 a}-\mathbf{i}$ may exist in one of two tautomeric forms $\mathbf{A}$ and $\mathbf{B}$ (Figure 2). To distinguish between these forms, ${ }^{13} \mathrm{C}-\mathrm{NMR}$ of compounds $\mathbf{6 b}-\mathbf{f}$ were recorded. The spectra showed two carbonyl signals corresponding to the pyrimidinone $\mathrm{C}=\mathrm{O}$ at 166.61-160.36 and the benzoyl $\mathrm{C}=\mathrm{O}$ at 194.50-194.09 ppm. Based on literature reports [23-27], the chemical shift of the pyrimidinone carbonyl is markedly affected by the nature of the adjacent nitrogen. The $\delta$ values of the pyrimidinone $\mathrm{C}=\mathrm{O}$ in compounds $\mathbf{6 b}-\mathbf{f}$ suggest that $\mathrm{N}-(3)$ near to $\mathrm{C}=\mathrm{O}$ is $\mathrm{sp}^{3}$-hybridized (pyrrole type) as it is similar to that found in the methyl derivative $\mathbf{1 0}$ and different from the $\mathrm{C}=\mathrm{O}$ adjacent to $\mathrm{sp}^{2}$-hybridized nitrogen (pyridine type), which appears at 175-170 ppm (compound 11) [26,27] (Figure 2). Accordingly, compounds 6a-i are found as one tautomeric form namely, A rather $\mathbf{B}$.

Figure 2. Possible tautomeric structures of compounds $\mathbf{6 a}-\mathbf{i}$ and ${ }^{13} \mathrm{C}-\mathrm{NMR}$ chemical shifts of reported thiouracils.

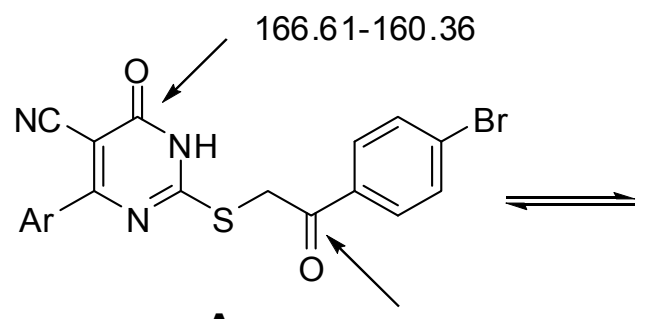

A

194.50-194.09<smiles>N#Cc1c(Br)[nH]c(SCC(=O)c2ccc(Br)cc2)nc1=O</smiles>

B<smiles>[R]Sc1nc([R])cc(=O)n1C</smiles><smiles>[R]Sc1nc(=O)cc([R])n1C</smiles>

10

11

Reaction of compound $\mathbf{6 a}, \mathbf{6 c}$ or $\mathbf{6 e}$ with diazotized $p$-aminophenol in aqueous sodium hydroxide solution at $-5{ }^{\circ} \mathrm{C}$ produced the corresponding arylhydrazono derivatives $7 \mathbf{a}-\mathbf{c}$ (Scheme 2). Compounds 7a-c can exist in one or more of four tautomeric structures $\mathbf{C}-\mathbf{F}$ (Figure 3). Their IR spectral data seem to be consistent more with the hydrazone structures $(\mathbf{C}$ or $\mathbf{D})$ rather than the enolazo tautomeric forms (E or F). For example, all compounds exhibited two carbonyl bands in the regions 1654-1632 and $1670-1660 \mathrm{~cm}^{-1}$ corresponding to the stretching vibrations of the pyrimidinone and the benzoyl 
carbonyl groups, respectively. The low value of the wave number assigned for the latter $\mathrm{C}=\mathrm{O}$ stretching band appears to result from chelation with $\mathrm{NH}$ and conjugation with the $\mathrm{C}=\mathrm{N}$ double bond as required by hydrazone form $\mathbf{C}$ or $\mathbf{D}[28,29]$. The ${ }^{1} \mathrm{H}-\mathrm{NMR}$ showed three exchangeable singlet signals at the range of 9.41-13.20 ppm due to the phenolic $\mathrm{OH}$, the hydrazone $\mathrm{NH}$ and the pyrimidinone $\mathrm{NH}$, while those derived from $\mathrm{SCH}_{2}$ were not detected. Finally, to differentiate between the $\mathbf{C}$ and $\mathbf{D}$ tautomers (Figure 3), the ${ }^{13} \mathrm{C}-\mathrm{NMR}$ spectrum of $7 \mathbf{c}$ was recorded and compared with those of $\mathbf{6 b}-\mathbf{f}$. The pyrimidinone $\mathrm{C}=\mathrm{O}$ was detected at $161.04 \mathrm{ppm}$ similar to those of $\mathbf{6 b}-\mathbf{f}$ and $\mathbf{1 0}$. This finding indicates that the hydrazone derivatives $\mathbf{7 a}-\mathbf{c}$ exist predominantly in form $\mathbf{C}$.

Figure 3. Possible tautomeric structures of compounds $7 \mathbf{a}-\mathbf{c}$.<smiles></smiles>

Refluxing 6c with triethyl orthoformate in acetic anhydride gave the thiazolo[3,2-a]pyrimidine derivative 9 instead of the expected ethoxy methene derivative $\mathbf{8}$, as a result of intramolecular cyclization of the latter (Scheme 2). The ${ }^{1} \mathrm{H}$-NMR spectrum of the product revealed the disappearance of $\mathrm{SCH}_{2}$ signal and the appearance of a singlet signal at $7.65 \mathrm{ppm}$ assigned for the thiazole $\mathrm{CH}$. A notable feature in the ${ }^{1} \mathrm{H}-\mathrm{NMR}$ spectrum was the absence of the triplet-quartet pattern of the ethoxy group and $\mathrm{D}_{2} \mathrm{O}$ exchangeable $(\mathrm{NH})$ signal, which asserted the production of the cyclic thiazolo[3,2-a]pyrimidine derivative 9.

\subsection{Biological Evaluation}

\subsubsection{Antimicrobial Activity}

The newly synthesized compounds were evaluated for their in vitro antibacterial activity against Staphylococcus aureus ATCC 6538P, Bacillus subtilis ATCC CC33, Escherichia coli ATCC 5087 and 
Pseudomonas aeruginosa ATCC 9027, as well as for their antifungal activity against Candida albicans ATCC 60193 and Aspergillus niger ATCC 1718109 using the microbroth dilution method [30]. The minimum inhibitory concentration (MIC) and concentration that inhibit $50 \%$ of microorganisms ( $\mathrm{IC}_{50}$ ) as measures of the microbial inhibitory activity as well as minimum bactericidal concentration (MBC) that reflects the bactericidal activity of the tested compounds were calculated at $\mu \mathrm{g} / \mathrm{mL}$ (Table1). The data presented in Table 1 revealed that compounds $\mathbf{6 a}$ and $\mathbf{6 c}$ had good to fair broad spectrum antibacterial activity, other compounds $4 \mathbf{d}, 4 \mathbf{h}, \mathbf{6 f}, \mathbf{6 g}, 7 \mathbf{a}-\mathbf{c}$ were only active against Gram positive strains. As for antifungal activity, compound $\mathbf{4 g}$ exhibited moderate activity against $C$. albicans and $A$. niger, while 9 elicited weak antifungal activity against $A$. niger with Gram positive antibacterial activity. Among the tested compounds, only compound 4i displayed pronounced broad spectrum antibacterial and antifungal activities. On the other hand, the remaining compounds $6 \mathbf{6 b}, \mathbf{6 d}, \mathbf{6 e}, \mathbf{6 h}$ and 6i had no significant activity against any of the tested strains at concentration up to $50 \mu \mathrm{g} / \mathrm{mL}$ (Figure 4).

Table 1. Antimicrobial activity of the synthesized compounds expressed as minimum inhibitory concentration (MIC), minimum bactericidal concentration (MBC) and concentration that inhibit $50 \%$ of microorganisms $\left(\mathrm{IC}_{50}\right)$ in $\mu \mathrm{g} / \mathrm{mL}$ against the pathological strains based on two fold serial dilution technique.

\begin{tabular}{|c|c|c|c|c|c|c|c|}
\hline \multirow{2}{*}{ Compound } & & \multicolumn{2}{|c|}{ Gram positive bacteria } & \multicolumn{2}{|c|}{ Gram negative bacteria } & \multicolumn{2}{|c|}{ Fungi } \\
\hline & & S. aureus & B. subtlis & E. coli & P. aeruginosa & C. albicans & A. niger \\
\hline \multirow[t]{3}{*}{$4 d$} & MIC & 9.38 & 9.38 & $>50$ & $>50$ & $>50$ & $>50$ \\
\hline & MBC & 9.30 & 9.30 & $>50$ & $>50$ & $>50$ & $>50$ \\
\hline & $\mathrm{IC}_{50}$ & 4.20 & 6.25 & $>50$ & $>50$ & $>50$ & $>50$ \\
\hline \multirow[t]{3}{*}{$4 g$} & MIC & $>50$ & $>50$ & $>50$ & $>50$ & 9.38 & 18.75 \\
\hline & MBC & $>50$ & $>50$ & $>50$ & $>50$ & 9.30 & 18.75 \\
\hline & $\mathrm{IC}_{50}$ & $>50$ & $>50$ & $>50$ & $>50$ & 6.25 & 12.50 \\
\hline \multirow[t]{3}{*}{$4 h$} & MIC & 1.17 & 1.17 & $>50$ & $>50$ & $>50$ & $>50$ \\
\hline & MBC & 1.56 & 1.56 & $>50$ & $>50$ & $>50$ & $>50$ \\
\hline & $\mathrm{IC}_{50}$ & 0.40 & 0.78 & $>50$ & $>50$ & $>50$ & $>50$ \\
\hline \multirow[t]{3}{*}{$4 i$} & MIC & 2.34 & 9.38 & 9.38 & 9.38 & 2.34 & 4.69 \\
\hline & $\mathrm{MBC}$ & 2.30 & 9.30 & 9.30 & 9.30 & 2.30 & 6.25 \\
\hline & $\mathrm{IC}_{50}$ & 1.17 & 6.25 & 3.13 & 3.13 & 1.17 & 3.13 \\
\hline \multirow[t]{3}{*}{$6 a$} & MIC & 4.69 & 9.38 & 18.75 & 37.50 & $>50$ & $>50$ \\
\hline & $\mathrm{MBC}$ & 3.80 & 9.00 & 18.75 & 37.50 & $>50$ & $>50$ \\
\hline & $\mathrm{IC}_{50}$ & 2.30 & 6.25 & 12.50 & 25.00 & $>50$ & $>50$ \\
\hline \multirow[t]{3}{*}{$6 \mathrm{~b}$} & MIC & $>50$ & $>50$ & $>50$ & $>50$ & $>50$ & $>50$ \\
\hline & $\mathrm{MBC}$ & $>50$ & $>50$ & $>50$ & $>50$ & $>50$ & $>50$ \\
\hline & $\mathrm{IC}_{50}$ & $>50$ & $>50$ & $>50$ & $>50$ & $>50$ & $>50$ \\
\hline \multirow[t]{3}{*}{$6 c$} & MIC & 37.50 & 37.50 & 37.50 & 37.50 & $>50$ & $>50$ \\
\hline & MBC & 37.50 & 37.50 & 37.50 & 37.50 & $>50$ & $>50$ \\
\hline & $\mathrm{IC}_{50}$ & 12.50 & 25.00 & 25.00 & 25.00 & $>50$ & $>50$ \\
\hline \multirow[t]{3}{*}{ 6d } & MIC & $>50$ & $>50$ & $>50$ & $>50$ & $>50$ & $>50$ \\
\hline & $\mathrm{MBC}$ & $>50$ & $>50$ & $>50$ & $>50$ & $>50$ & $>50$ \\
\hline & $\mathrm{IC}_{50}$ & $>50$ & $>50$ & $>50$ & $>50$ & $>50$ & $>50$ \\
\hline
\end{tabular}


Table 1. Cont.

\begin{tabular}{|c|c|c|c|c|c|c|c|}
\hline \multirow[t]{2}{*}{ Compound } & & \multicolumn{2}{|c|}{ Gram positive bacteria } & \multicolumn{2}{|c|}{ Gram negative bacteria } & \multicolumn{2}{|c|}{ Fungi } \\
\hline & & S. aureus & B. subtlis & E. Coli & P. aeruginosa & C. albicans & A. niger \\
\hline \multirow[t]{3}{*}{$6 e$} & MIC & $>50$ & $>50$ & $>50$ & $>50$ & $>50$ & $>50$ \\
\hline & MBC & $>50$ & $>50$ & $>50$ & $>50$ & $>50$ & $>50$ \\
\hline & $\mathrm{IC}_{50}$ & $>50$ & $>50$ & $>50$ & $>50$ & $>50$ & $>50$ \\
\hline \multirow[t]{3}{*}{$6 f$} & MIC & 2.34 & 4.69 & $>50$ & $>50$ & $>50$ & $>50$ \\
\hline & MBC & 3.13 & 6.25 & $>50$ & $>50$ & $>50$ & $>50$ \\
\hline & $\mathrm{IC}_{50}$ & 1.56 & 3.13 & $>50$ & $>50$ & $>50$ & $>50$ \\
\hline \multirow[t]{3}{*}{$6 \mathrm{~g}$} & MIC & 4.69 & 4.69 & $>50$ & $>50$ & $>50$ & $>50$ \\
\hline & MBC & 4.70 & 4.70 & $>50$ & $>50$ & $>50$ & $>50$ \\
\hline & $\mathrm{IC}_{50}$ & 1.56 & 1.56 & $>50$ & $>50$ & $>50$ & $>50$ \\
\hline \multirow[t]{3}{*}{$6 h$} & MIC & $>50$ & $>50$ & $>50$ & $>50$ & $>50$ & $>50$ \\
\hline & $\mathrm{MBC}$ & $>50$ & $>50$ & $>50$ & $>50$ & $>50$ & $>50$ \\
\hline & $\mathrm{IC}_{50}$ & $>50$ & $>50$ & $>50$ & $>50$ & $>50$ & $>50$ \\
\hline \multirow[t]{3}{*}{$6 i$} & MIC & $>50$ & $>50$ & $>50$ & $>50$ & $>50$ & $>50$ \\
\hline & $\mathrm{MBC}$ & $>50$ & $>50$ & $>50$ & $>50$ & $>50$ & $>50$ \\
\hline & $\mathrm{IC}_{50}$ & $>50$ & $>50$ & $>50$ & $>50$ & $>50$ & $>50$ \\
\hline \multirow[t]{3}{*}{$7 a$} & MIC & 18.75 & 18.75 & $>50$ & $>50$ & $>50$ & $>50$ \\
\hline & $\mathrm{MBC}$ & 18.75 & 18.75 & $>50$ & $>50$ & $>50$ & $>50$ \\
\hline & $\mathrm{IC}_{50}$ & 12.50 & 12.50 & $>50$ & $>50$ & $>50$ & $>50$ \\
\hline \multirow[t]{3}{*}{$7 \mathrm{~b}$} & MIC & 1.17 & 2.34 & $>50$ & $>50$ & $>50$ & $>50$ \\
\hline & $\mathrm{MBC}$ & 1.17 & 2.30 & $>50$ & $>50$ & $>50$ & $>50$ \\
\hline & $\mathrm{IC}_{50}$ & 0.78 & 1.17 & $>50$ & $>50$ & $>50$ & $>50$ \\
\hline \multirow[t]{3}{*}{$7 \mathrm{c}$} & MIC & 0.19 & 1.17 & $>50$ & $>50$ & $>50$ & $>50$ \\
\hline & MBC & 0.20 & 1.17 & $>50$ & $>50$ & $>50$ & $>50$ \\
\hline & $\mathrm{IC}_{50}$ & 0.15 & 0.40 & $>50$ & $>50$ & $>50$ & $>50$ \\
\hline \multirow[t]{3}{*}{9} & MIC & 37.50 & 37.50 & $>50$ & $>50$ & $>50$ & 37.50 \\
\hline & $\mathrm{MBC}$ & 37.50 & 50.00 & $>50$ & $>50$ & $>50$ & 50.00 \\
\hline & $\mathrm{IC}_{50}$ & 12.50 & 37.50 & $>50$ & $>50$ & $>50$ & 37.50 \\
\hline Amoxicillin & MIC & 1.25 & 150 & NA & NA & NA & $\mathrm{NA}$ \\
\hline Gentamicin & MIC & NA & NA & 1.00 & 8.00 & NA & NA \\
\hline Amphotericin B & MIC & NA & NA & NA & NA & 3.00 & 1.25 \\
\hline
\end{tabular}

Figure 4. The antimicrobial spectrum of tested compounds.

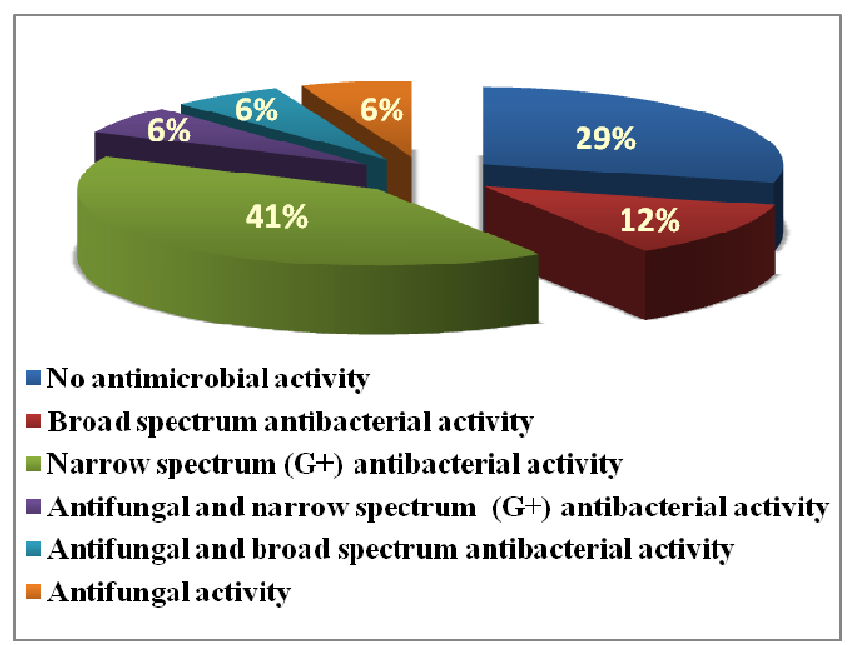


The structure activity correlation of the tested compounds showed that, the starting 6-aryl-5-cyano2-thiouracil derivatives $\mathbf{4 d}, \mathbf{4 g}-\mathbf{i}$ had moderate to potent antimicrobial activity. Both the antimicrobial spectrum and potency of such compounds seem to be dependent on the the aryl substituent at the 6 position of the thiouracil ring. Compound $\mathbf{4 d}$ with a 2,6-dichlorophenyl was moderately active against Gram positive bacteria only. An eight-fold increase in inhibitory activity against the same bacterial isolates was observed with methylfuran analog $\mathbf{4 h}$. Appending a methylthiophene to the thiouracil ring as in $4 \mathbf{i}$ changed the antimicrobial spectrum from narrow to broad. $S$. aureus was the most sensitive bacteria to $4 \mathbf{i}$ followed by $B$. subtilis, E. coli and P. aeruginosa. Moreover, it exhibited the highest antifungal activity against $C$. albicans, even stronger than the reference drug amphotericin B (MIC $=2.34$, $3.00 \mu \mathrm{g} / \mathrm{mL}$ respectively) and fairly potent activity against A. niger. On the other hand, modest antifungal activity was observed for the trimethoxyphenyl congener $\mathbf{4 g}$.

Considering the $S$-bromobenzoylmethyl thiouracil derivatives $\mathbf{6 a}-\mathbf{i}$, they proved to have no antifungal activity. This suggested that $S$-alkylation has a negative impact on the antifungal activity of the synthesized thiouracils ( $\mathbf{4 g}$ versus $\mathbf{6 g}$ and $4 \mathbf{i}$ versus $\mathbf{6 i})$. On the other hand, the antibacterial activity of such compounds appears to be affected by the nature of aryl substituent on the thiouracil scaffold. Compound 6a with an unsubstituted phenyl group displayed good activity against $S$. aureus and B. subtilis, in addition to moderate to low activity against the Gram-negative E. coli and P. aeruginosa. Meanwhile, the presence of a phenyl-bearing mesomeric electron-donating methoxy group resulted in compounds $\mathbf{6 f}$ and $\mathbf{6 g}$ with enhanced activity against Gram positive bacteria only. Conversely, analogs with heteroaryl substituent $\mathbf{6 h}$ and $\mathbf{6 i}$ or phenyl attached to inductive electron-donating or electron withdrawing atoms as in $\mathbf{6 b}-\mathbf{e}$ were either inactive or weakly active against the investigated bacteria, assuming that the electronic nature of the substituents is of major importance.

The incorporation of a 4-hydroxyphenylhydrazono moiety to the active methylene in $\mathbf{6 a}, \mathbf{6 c}$ and $\mathbf{6 e}$ produced 7a-c with remarkable inhibition effect against Gram positive S. aureus and B. subtilis. Compound 7a with phenyl substituent at the 6-postion of the thiouracil ring possessed moderate activity. However, the more lipophilic $p$-bromophenyl $\mathbf{7 b}$ and $p$-tolyl $\mathbf{7 c}$ analogs had superior antibacterial activity compared to the reference drug amoxicillin. In particular, 7c being the most potent antibacterial agent in this study with MIC 0.19 and $1.17 \mu \mathrm{g} / \mathrm{mL}$ against $S$. aureus and B. subtilis, respectively, indicating that, the presence of an electron-donating methyl group is more favorable for the antibacterial effect of this class of compounds than electron-withdrawing bromine atom. Also, the excellent antibacterial activity of $\mathbf{7 a - c}$ might be attributed to the presence of 4-hydroxyphenylhydrazono moiety. It has been reported [31-33], that phenolic compounds can sensitize the phospholipid bilayer of the microbial cytoplasmic membrane causing increased permeability, unavailability of vital intracellular constituents and/or impairment of bacterial enzyme systems related to energy production.

The cyclization of $\mathbf{6 c}$ into the corresponding thiazolo[3,2-a]pyrimidine derivative $\mathbf{9}$ affected the microbial spectrum rather than potency. While, $\mathbf{6 c}$ proved to have mild broad spectrum antibacterial activity with no antifungal activity, 9 demonstrated weak antimicrobial activities toward Gram positive bacterial strains and the fungus A. niger. Finally, the narrow concentration difference between the MIC and $\mathrm{MBC}$ of active compounds indicated that they have bactericidal effects rather than bacteriostatic ones. 


\subsubsection{Anticancer Activity}

Thirteen compounds $\mathbf{4 d}, \mathbf{4 g}-\mathbf{i}$ and $\mathbf{6 a}-\mathbf{i}$ were selected by the National Cancer Institute (NCI) Developmental Therapeutic Program (www.dtp.nci.nih.gov) to be screened for their anticancer activity in vitro. The anticancer assays were performed in accordance with the protocol of the Drug Evaluation Branch, NCI, Bethesda [34-36]. The compounds were first evaluated at one dose primary anticancer assay towards a panel of approximately 60 cancer lines (concentration $10^{-5} \mathrm{M}$ ). The human tumor cell lines were derived from nine different cancer types: leukemia, melanoma, lung, colon, central nervous system (CNS), ovarian, renal, prostate and breast cancers. A $48 \mathrm{~h}$ drug exposure protocol was used and sulforhodamine B (SRB) protein assay was applied to estimate the cell viability and growth [37]. Results for each tested agent were reported as the percentage growth of the treated cells compared to the untreated control cells and also, presented as mean graph of the growth present. The preliminary screening results (Table 2) showed that most of the compounds had limited cytotoxic activity against the tested cell lines with percentage growth ranging from 73.09 to $133.71 \%$. Nevertheless, compounds 6d and 6i displayed potent growth inhibitory potency toward non-small cell lung cancer HOP-92 and leukemia MOLT-4 with growth \% 41.03 and 42.38, respectively.

Regarding sensitivity of individual cell lines, all the evaluated compounds exhibited a distinguished sensitivity profile toward one or more of the renal cancer cell lines in comparison with other cell lines, namely UO-31, A498 or 786-0. Moreover, compounds 4i and 6i restrained the growth of melanoma LOX IMVI cancer cell line. It is noteworthy that both compounds have highly lipophilic methylthiophen motif as substituent on thiouracil moiety, which might increase their availability and penetration to melanoma cells. In addition, compounds $\mathbf{6 d}$ and $\mathbf{6 i}$ were found especially effective against non-small cell lung cancer HOP-92 and leukemia MOLT-4, respectively.

Structurally, elaborating the thiouracils $4 \mathbf{g}-\mathbf{i}$ with bromobenzoylmethyl moiety in $\mathbf{6 g}-\mathbf{i}$ led to compounds that had comparable or slightly better inhibitory efficacy with almost similar antitumor spectrum. For instance, the analogue 6i exhibited a marginal activity increase toward the same melanoma and renal cancer cell lines as $\mathbf{4 i}$, in addition to remarkable high activity against MOLT-4 leukemia cell line (growth \% 42.38). Interestingly, applying the same structure modification to 4d afforded $\mathbf{6 d}$ with a unique broad anticancer spectrum. The latter, elicited the highest growth inhibitory potential against seven tumor sub-panels; leukemia, colon cancer, CNS cancer, melanoma, renal cancer and breast cancer with noticeable antiproliferative effect on non small lung cancer HOP-92 (growth \% 41.03).

Eventually, it seems that the position rather than electronic nature of substituents on 6-aryl group of thiouracil ring had a prominent effect on the activity profile of compounds $\mathbf{6 a}-\mathbf{i}$. The steric hindrance generated by the ortho-ortho dichloro substituents on the 6-aryl in $\mathbf{6 d}$ can create constrain and impose particular orientation of the aryl group relative to the rest of the molecule. Such conformation might be favorable to cytotoxicity and could explain the observed activity of $\mathbf{6 d}$. In brief, the coexistence of methylthiophene or 2,6-dichlophenyl at position 6 and bromobezoylmethyl moiety at position 2 of the thiouracil ring increases the cytotoxic activity against specific cell lines. 
Table 2. Cytotoxic activity of the tested compounds against a panel of 60 cancer cell lines at $10 \mu \mathrm{M}$ concentration.

\begin{tabular}{|c|c|c|c|c|}
\hline Compound & $\begin{array}{c}\text { Mean } \\
\text { growth, \% }\end{array}$ & $\begin{array}{c}\text { Range of } \\
\text { growth, \% }\end{array}$ & Panel & $\begin{array}{c}\text { Most sensitive cell lines } \\
\text { growth, } \%\end{array}$ \\
\hline 4d & 102.90 & $76.85-126.64$ & Renal Cancer & UO-31 (76.85) \\
\hline $4 \mathrm{~g}$ & 102.53 & $81.19-121.32$ & Renal Cancer & A498 (81.19) \\
\hline $4 h$ & 104.95 & $82.37-133.71$ & Renal Cancer & UO-31 (82.37) \\
\hline \multirow{2}{*}{$4 i$} & 105.24 & $76.99-127.08$ & Melanoma & L OX IMVI (76.99) \\
\hline & & & Renal Cancer & 786-0 (83.54), UO-31 (84.31) \\
\hline 6a & 102.14 & $80.39-119.48$ & Renal Cancer & A498 (85.49), UO-31 (80.39) \\
\hline 6b & 103.26 & $80.27-121.43$ & Renal Cancer & $\mathrm{A} 498(80.27)$ \\
\hline 6c & 102.26 & $80.07-117.90$ & Renal Cancer & $\mathrm{A} 498(80.07)$ \\
\hline \multirow[t]{14}{*}{ 6d } & 89.03 & $41.03-118.60$ & Leukemia & HL-60(TB) (75.34), K-562 \\
\hline & & & & (73.85), MOLT-4 (73.33), \\
\hline & & & & RPMI-8226 (72.35), SR (79.59). \\
\hline & & & Non Small Cell Lung & EKVX (79.94), HOP-92 (41.03), \\
\hline & & & Cancer & NCI-H522 (75.25). \\
\hline & & & & НCТ-116 (74.54), \\
\hline & & & & HTC-15 (80.89). \\
\hline & & & Colon Cancer & SF-295 (81.77) \\
\hline & & & CNS Cancer & SK-MEL-2 (82.18), \\
\hline & & & Melanoma & UACC-62 (80.12) \\
\hline & & & Renal Cancer & 780-0 (73.64), A498 (75.93), \\
\hline & & & & CAKI-1 (71.34), UO-31 (80.25). \\
\hline & & & Breast Cancer & MCF-7 (83.81), T-47D (74.23), \\
\hline & & & & MDA-MB-468 (73.27) \\
\hline $6 e$ & 101.92 & $82.81-119.49$ & Renal Cancer & UO-31 (82.81) \\
\hline \multirow[t]{3}{*}{$6 f$} & 102.30 & $78.50-121.80$ & Non-Small Cell Lung & HOP-92 (85.86) \\
\hline & & & Cancer & \\
\hline & & & Renal Cancer & A498 (78.50), UO-31 (86.29) \\
\hline $6 \mathrm{~g}$ & 102.98 & $83.81-124.78$ & Renal Cancer & A498 (84.19), UO-31 (83.81) \\
\hline $6 \mathbf{h}$ & 101.72 & $73.09-114.65$ & Renal Cancer & UO-31 (73.09) \\
\hline \multirow[t]{3}{*}{$6 \mathbf{i}$} & 102.41 & $42.38-119.33$ & Leukemia & MOLT-4 (42.38) \\
\hline & & & Melanoma & L OX IMVI (75.06) \\
\hline & & & Renal Cancer & 786-0 (81.16), UO-31 (80.26) \\
\hline
\end{tabular}

\section{Experimental}

\subsection{Chemistry}

Melting points are uncorrected and determined in one end open capillary tubes using Gallenkamp melting point apparatus MFB-595-010M (Gallenkamp, London, England). Microanalysis was carried out at Micro-analytical Unit, Regional Centre for Microbiology and Biotechnology, Al-Azhar University. Infrared spectra were recorded on a Shimadzu FT-IR 8400S spectrophotometer (Shimadzu, Kyoto, Japan), using potassium bromide discs and results are expressed in wave numbers $\left(\mathrm{cm}^{-1}\right)$. The NMR spectra were recorded on a Varian Mercury VX-300 NMR spectrometer. ${ }^{1} \mathrm{H}$ - spectra were run at 
$300 \mathrm{MHz}$ and ${ }^{13} \mathrm{C}$ - spectra were run at $75.46 \mathrm{MHz}$ in dimethylsulphoxide (DMSO- $d_{6}$ ). Chemical shifts are quoted in $\delta$ and were related to that of the solvents. Mass spectra were recorded using a Hewlett Packard Varian (Varian, Palo Alto, CA, USA) and Shimadzu Gas Chromatograph Mass SpectrometerQP 1000 EX (Shimadzu, Kyoto, Japan). TLC were carried out using Art.DC-Plastikfolien, Kieselgel 60 F254 sheets (Merck, Darmstadt, Germany), the developing solvents were chloroform/methanol (9:1) and the spots were visualized at 366 and $254 \mathrm{~nm}$ by UV Vilber Lourmat 77,202 (Vilber, Marne La Vallee, France). Compounds $4 \mathbf{a}-\mathbf{c}$ and $\mathbf{4 e -} \mathbf{g}$ were obtained according to the reported procedures [15,18,38-40], while compound $\mathbf{6 a}$ is commercially available.

6-Aryl-4-oxo-2-thioxo-1,2,3,4-tetrahydropyrimidine-5-carbonitriles $\mathbf{4 a - i .}$ A mixture of ethyl cyanoacetate $1(1.13 \mathrm{~g}, 1.07 \mathrm{~mL}, 0.01 \mathrm{~mol})$, thiourea $3(0.76 \mathrm{~g}, 0.01 \mathrm{~mol})$, anhydrous potassium carbonate $(2.07 \mathrm{~g}, 0.015 \mathrm{~mol})$ and the appropriate aromatic aldehyde $2(0.01 \mathrm{~mol})$ in absolute ethanol $(25 \mathrm{~mL})$ was heated under reflux for $12 \mathrm{~h}$. The reaction mixture was allowed to cool and the formed precipitate was filtered. The residue was triturated with water and neutralized with acetic acid. The precipitate was filtered, washed twice with cold water $(20 \mathrm{~mL})$, dried, and crystallized from ethanol.

6-(2,6-Dichlorophenyl)-4-oxo-2-thioxo-1,2,3,4-tetrahydropyrimidine-5-carbonitrile (4d): Yield 55\%, m.p: $261-263{ }^{\circ} \mathrm{C} .{ }^{1} \mathrm{H}-\mathrm{NMR}: \delta$ : 7.48-7.60 (3H, m), $7.63(1 \mathrm{H}, \mathrm{d}, J=7.8), 7.86(1 \mathrm{H}, \mathrm{d}, J=6.9) .{ }^{13} \mathrm{C}-\mathrm{NMR}$ $\delta: 125.03,128.18,128.37,129.09,130.97,137.35,159.94,160.00,176.13 . \mathrm{IR} \mathrm{cm}^{-1}: 3344$ and 3124 $(\mathrm{NH}), 3012(\mathrm{CH}$ aromatic), 2939 and $2900(\mathrm{CH}$ aliphatic), $2206(\mathrm{C} \equiv \mathrm{N}), 1631(\mathrm{C}=\mathrm{O}), 1253(\mathrm{C}=\mathrm{S})$. Anal. Calcd. for $\mathrm{C}_{11} \mathrm{H}_{5} \mathrm{Cl}_{2} \mathrm{~N}_{3} \mathrm{OS}$ (298.15): C, 44.31; H, 1.69; N, 14.09. Found: C, 44.61; H, 1.77; N, 14.28.

4-Oxo-2-thioxo-6-(3,4,5-trimethoxyphenyl)-1,2,3,4-tetrahydropyrimidine-5-carbonitrile (4g) [15]: Yield 62\%, m.p: $250-252{ }^{\circ} \mathrm{C}$, (reported m.p: $\left.245-247{ }^{\circ} \mathrm{C}\right) .{ }^{1} \mathrm{H}-\mathrm{NMR} \delta: 3.73(3 \mathrm{H}, \mathrm{s}), 3.82(6 \mathrm{H}, \mathrm{s}), 6.61$ $(2 \mathrm{H}, \mathrm{s}), 11.53\left(2 \mathrm{H}\right.$, br s). ${ }^{13} \mathrm{C}-\mathrm{NMR} \delta: 55.69,60.05,84.84,106.27,119.05,132.64,138.95,152.13$, 152.54, 162.54, 166.65, 182.56. IR cm $\mathrm{cm}^{-1}: 3344$ and $3294(\mathrm{NH}), 3136(\mathrm{CH}$ aromatic), 2954 and 2839 (CH aliphatic), $2152(\mathrm{C} \equiv \mathrm{N}), 1627(\mathrm{C}=\mathrm{O}), 1246(\mathrm{C}=\mathrm{S})$. Anal. Calcd. for $\mathrm{C}_{14} \mathrm{H}_{13} \mathrm{~N}_{3} \mathrm{O}_{4} \mathrm{~S}$ (319.34): C, 52.66; H, 4.10; N, 13.16. Found: C, 52.86; H, 4.23; N, 13.52 .

6-(5-Methylfuran-2-yl)-4-oxo-2-thioxo-1,2,3,4-tetrahydropyrimidine-5-carbonitrile (4h): Yield 48\%, m.p: $242{ }^{\circ} \mathrm{C}$ decomp. ${ }^{1} \mathrm{H}-\mathrm{NMR} \delta: 2.36(3 \mathrm{H}, \mathrm{s}), 6.33(1 \mathrm{H}, \mathrm{d}, J=2.2), 7.20(1 \mathrm{H}, \mathrm{d}, J=2.2), 11.47$ (2H, br $\mathrm{s}, \mathrm{D}_{2} \mathrm{O}$ exchangeable). IR cm ${ }^{-1}: 3394$, br $(\mathrm{NH}), 3039$ ( $\mathrm{CH}$ aromatic), 2924 and 2854 ( $\mathrm{CH}$ aliphatic), $2214(\mathrm{C} \equiv \mathrm{N}), 1652(\mathrm{C}=\mathrm{O}), 1222(\mathrm{C}=\mathrm{S})$. Anal. Calcd. for $\mathrm{C}_{10} \mathrm{H}_{7} \mathrm{~N}_{3} \mathrm{O}_{2} \mathrm{~S}(233.03)$ : C, 51.49; H, 3.02; N, 18.02. Found: C, 51.62; H, 3.14; N, 18.09 .

6-(5-Methylthiophen-2-yl)-4-oxo-2-thioxo-1,2,3,4-tetrahydropyrimidine-5-carbonitrile (4i): Yield 45\%, m.p: $201-203{ }^{\circ} \mathrm{C} .{ }^{1} \mathrm{H}-\mathrm{NMR} \delta: 2.48(3 \mathrm{H}, \mathrm{s}), 6.89(1 \mathrm{H}, \mathrm{d}, J=3.6), 7.44(1 \mathrm{H}, \mathrm{d}, J=3.9), 11.45$ (2H, br s, $\mathrm{D}_{2} \mathrm{O}$ exchangeable). IR cm ${ }^{-1}: 3410$, br (NH), 3093 (CH aromatic), 2920 and 2854 (CH aliphatic), 2210 $(\mathrm{C} \equiv \mathrm{N}), 1625(\mathrm{C}=\mathrm{O}), 1242(\mathrm{C}=\mathrm{S})$. Anal. Calcd. for $\mathrm{C}_{10} \mathrm{H}_{7} \mathrm{~N}_{3} \mathrm{OS}_{2}$ (249.31): C, 48.18; H, 2.83; N, 16.85 . Found: C, 48.60; H, 2.90; N, 17.31. MS m/z: $249[\mathrm{M}]^{+}$.

6-Aryl-2-(4-bromobenzoylmethylthio)-4-oxo-3,4-dihydropyrimidine-5-carbonitriles 6a-i. To a solution of thiouracil derivatives $\mathbf{4 a}-\mathbf{i}(0.01 \mathrm{~mol})$ in dry benzene $(10 \mathrm{~mL})$ was added anhydrous potassium 
carbonate (4.14 g, $0.03 \mathrm{~mol})$ and bromophenacyl bromide 5 (2.78 g, $0.01 \mathrm{~mol})$. The mixture was heated under reflux for $24 \mathrm{~h}$. Then, the solvent was reduced under vacuum and the reaction mixture was cooled. The precipitate was filtered, washed twice with cold water, dried and crystallized from methanol.

2-(4-Bromobenzoylmethylthio)-4-oxo-6-phenyl-3,4-dihydropyrimidine-5-carbonitrile (6a): Yield 68\%, m.p: $242-244{ }^{\circ} \mathrm{C}$. IR cm ${ }^{-1}$ : 3429, br (NH), 3086 (CH aromatic), 2920 and 2854 (CH aliphatic), 2194 $(\mathrm{C} \equiv \mathrm{N}), 1701$ and $1631(\mathrm{C}=\mathrm{Os})$. Anal. Calcd. for $\mathrm{C}_{19} \mathrm{H}_{12} \mathrm{BrN}_{3} \mathrm{O}_{2} \mathrm{~S}$ (426.29): C, 53.53; H, 2.84; N, 9.86. Found: C, 53.42; H, 2.64; N, 10.14. MS m/z: $425[\mathrm{M}-1]^{+}$.

2-(4-Bromobenzoylmethylthio)-6-(4-chlorophenyl)-4-oxo-3,4-dihydropyrimidine-5-carbonitrile (6b): Yield 62\%, m.p: $248-250{ }^{\circ} \mathrm{C} .{ }^{1} \mathrm{H}-\mathrm{NMR} \delta$ : $4.55(2 \mathrm{H}, \mathrm{s}), 7.40(2 \mathrm{H}, \mathrm{d}, J=8.1), 7.63(2 \mathrm{H}, \mathrm{d}, J=8.1)$, $7.71(2 \mathrm{H}, \mathrm{d}, J=8.4), 7.94(2 \mathrm{H}, \mathrm{d}, J=8.4), 11.75\left(1 \mathrm{H}\right.$, br s, $\mathrm{D}_{2} \mathrm{O}$ exchangeable). ${ }^{13} \mathrm{C}-\mathrm{NMR} \delta: 37.26$, $89.06,119.69,127.21,127.92,129.73,130.24,131.60,134.32,135.25,136.12,165.49,169.91$, 170.69, 194.15. IR cm ${ }^{-1}$ : 3371, br (NH), 3105 (CH aromatic), 2916 (CH aliphatic), $2194(\mathrm{C} \equiv \mathrm{N}), 1697$ and 1650 (C=Os). Anal. Calcd. for $\mathrm{C}_{19} \mathrm{H}_{11} \mathrm{BrClN}_{3} \mathrm{O}_{2} \mathrm{~S}$ (460.73): C, 49.53; H, 2.41; N, 9.12. Found: $\mathrm{C}$, 49.46; H, 2.61; N, 9.42. MS m/z: $459[\mathrm{M}]^{+}, 461[\mathrm{M}+2]^{+}, 463[\mathrm{M}+4]^{+}$.

6-(4-Bromophenyl)-2-(4-bromobenzoylmethylthio)-4-oxo-3,4-dihydropyrimidine-5-carbonitrile (6c): Yield 68\%, m.p: $250-252{ }^{\circ} \mathrm{C} .{ }^{1} \mathrm{H}-\mathrm{NMR} \delta: 4.55(2 \mathrm{H}, \mathrm{s}), 7.52(2 \mathrm{H}, \mathrm{d}, J=8.1), 7.59-7.82(4 \mathrm{H}, \mathrm{m}), 7.93$ $(2 \mathrm{H}, \mathrm{d}, J=8.4), 11.70\left(1 \mathrm{H}\right.$, br s). ${ }^{13} \mathrm{C}-\mathrm{NMR} \delta: 37.26,88.97,119.71,123.085,123.54,127.23$, $128.41,129.77,130.19,130.85,131.59,135.20,162.37,169.86,170.72,194.09$. IR cm ${ }^{-1}: 3421$, br $(\mathrm{NH}), 3050(\mathrm{CH}$ aromatic), $2916(\mathrm{CH}$ aliphatic), $2194(\mathrm{C} \equiv \mathrm{N}), 1693-1628(\mathrm{C}=\mathrm{Os})$. Anal. Calcd. for $\mathrm{C}_{19} \mathrm{H}_{11} \mathrm{Br}_{2} \mathrm{~N}_{3} \mathrm{O}_{2} \mathrm{~S}$ (505.18): C, 45.17; H, 2.19; N, 8.32. Found: C, 45.19; H, 2.34; N, 8.47. MS m/z: 504 $[\mathrm{M}+1]^{+}, 505[\mathrm{M}+2]^{+}, 506[\mathrm{M}+3]^{+}, 507[\mathrm{M}+4]^{+}$.

2-(4-Bromobenzoylmethylthio)-6-(2,6-dichlorophenyl)-4-oxo-3,4-dihydropyrimidine-5-carbonitrile (6d): Yield 65\%, m.p: $>300{ }^{\circ} \mathrm{C} .{ }^{1} \mathrm{H}-\mathrm{NMR} \delta: 5.98(2 \mathrm{H}, \mathrm{s}), 7.23(3 \mathrm{H}, \mathrm{m}), 7.37(4 \mathrm{H}, \mathrm{d}, J=7.8), 8.74(1 \mathrm{H}$, s, $\mathrm{D}_{2} \mathrm{O}$ exchangeable). ${ }^{13} \mathrm{C}-\mathrm{NMR} \delta$ : 107.49, 116.46, 119.40, 123.17, 127.45, 128.39, 131.11, 132.54, 133.15, 135.26, 141.72, 147.03, 163.17, 169.64, 194.50. IR cm ${ }^{-1}: 3197$, br (NH), 3128 (CH aromatic), $2974\left(\mathrm{CH}\right.$ aliphatic), $2160(\mathrm{C} \equiv \mathrm{N}), 1735$ and $1619(\mathrm{C}=\mathrm{Os})$. Anal. Calcd. for $\mathrm{C}_{19} \mathrm{H}_{10} \mathrm{BrCl}_{2} \mathrm{~N}_{3} \mathrm{O}_{2} \mathrm{~S}$ (495.18): C, 46.09; H, 2.04; N, 8.49. Found: C, 46.13; H, 2.33; N, 8.86. MS m/z: $493[\mathrm{M}]^{+}, 494$ $[\mathrm{M}+1]^{+}, 495[\mathrm{M}+2]^{+}, 496[\mathrm{M}+3]^{+}$.

2-(4-Bromobenzoylmethylthio)-4-oxo-6-p-tolyl-3,4-dihydropyrimidine-5-carbonitrile (6e): Yield 70\%, m.p: $262-264{ }^{\circ} \mathrm{C} .{ }^{1} \mathrm{H}-\mathrm{NMR} \delta: 2.32(3 \mathrm{H}, \mathrm{s}), 4.89(2 \mathrm{H}, \mathrm{s}), 7.07(2 \mathrm{H}, \mathrm{d}, J=8.1), 7.50(2 \mathrm{H}, \mathrm{d}, J=8.1)$, $7.75(2 \mathrm{H}, \mathrm{d}, J=8.4), 7.95(2 \mathrm{H}, \mathrm{d}, J=8.4), 11.30\left(1 \mathrm{H}\right.$, br s, $\mathrm{D}_{2} \mathrm{O}$ exchangeable). ${ }^{13} \mathrm{C}-\mathrm{NMR} \delta: 20.85$, $37.23,88.78,120.06,127.19,128.13,128.43,130.25,131.59,134.57,135.25,139.22,166.61,170.27$, 170.43, 194.23. IR cm ${ }^{-1}$ : 3387, br (NH), 3012 (CH aromatic), 2916 (CH aliphatic), $2194(\mathrm{C} \equiv \mathrm{N}), 1701$ and $1631(\mathrm{C}=\mathrm{Os})$. Anal. Calcd. for $\mathrm{C}_{20} \mathrm{H}_{14} \mathrm{BrN}_{3} \mathrm{O}_{2} \mathrm{~S}$ (440.31): C, 54.56; H, 3.20; N, 9.54. Found: C, 54.83; H, 3.29; N, 9.82. MS m/z: $439[\mathrm{M}]^{+}, 441[\mathrm{M}+2]^{+}$.

2-(4-Bromobenzoylmethylthio)-6-(4-methoxyphenyl)-4-oxo-3,4-dihydropyrimidine-5-carbonitrile (6f): Yield 75\%, m.p: $285-287{ }^{\circ} \mathrm{C} .{ }^{1} \mathrm{H}-\mathrm{NMR} \delta: 3.82(3 \mathrm{H}, \mathrm{s}), 4.56(2 \mathrm{H}, \mathrm{s}), 6.87(2 \mathrm{H}, \mathrm{d}, J=6.9), 7.63(2 \mathrm{H}, \mathrm{d}$, 
$J=6.9), 7.72(2 \mathrm{H}, \mathrm{d}, J=6.9), 7.95(2 \mathrm{H}, \mathrm{d}, J=6.6), 11.55(1 \mathrm{H}, \mathrm{br} \mathrm{s}) .{ }^{13} \mathrm{C}-\mathrm{NMR} \delta: 37.27,55.20,88.25$, $113.18,120.35,127.24,129.56,129.64,129.66,130.33,131.66,135.25,160.36,166.02,170.36$, 194.22. IR cm ${ }^{-1}$ : 3394, br (NH), 3012 (CH aromatic), $2916(\mathrm{CH}$ aliphatic), $2194(\mathrm{C} \equiv \mathrm{N}), 1697$ and 1635 (C=Os). Anal. Calcd. for $\mathrm{C}_{20} \mathrm{H}_{14} \mathrm{BrN}_{3} \mathrm{O}_{3} \mathrm{~S}$ (456.31): C, 52.64; H, 3.09; N, 9.21. Found: C, 52.28; $\mathrm{H}, 3.19 ; \mathrm{N}, 9.53$. MS m/z: $455[\mathrm{M}]^{+}, 457[\mathrm{M}+2]^{+}$.

2-(4-Bromobenzoylmethylthio)-4-oxo-6-(3,4,5-trimethoxyphenyl)-3,4-dihydropyrimidine-5-carbonitrile (6g): Yield 55\%, m.p: $>300{ }^{\circ} \mathrm{C} .{ }^{1} \mathrm{H}-\mathrm{NMR} \delta: 3.80(3 \mathrm{H}, \mathrm{s}), 3.82(3 \mathrm{H}, \mathrm{s}), 3.84(3 \mathrm{H}, \mathrm{s}), 5.23(2 \mathrm{H}, \mathrm{s}), 7.06$ $(1 \mathrm{H}, \mathrm{s}), 7.19(1 \mathrm{H}, \mathrm{s}), 7.39(2 \mathrm{H}, \mathrm{d}, J=8.7), 7.85(2 \mathrm{H}, \mathrm{d}, J=8.7), 10.10$ (1H, br s, $\mathrm{D}_{2} \mathrm{O}$ exchangeable). IR $\mathrm{cm}^{-1}$ : 3425, br (NH), 3012 (CH aromatic), $2924(\mathrm{CH}$ aliphatic), $2200(\mathrm{C} \equiv \mathrm{N}), 1701$ and 1635 $(\mathrm{C}=\mathrm{Os})$. Anal. Calcd. for $\mathrm{C}_{22} \mathrm{H}_{18} \mathrm{BrN}_{3} \mathrm{O}_{5} \mathrm{~S}$ (516.36): C, 51.17; H, 3.51; N, 8.14. Found: C, 51.29; H, $3.22 ; \mathrm{N}, 8.54$. MS $m / z: 515[\mathrm{M}]^{+}$.

2-(4-Bromobenzoylmethylthio)-6-(5-methylfuran-2-yl)-4-oxo-3,4-dihydropyrimidine-5-carbonitrile (6h): Yield 40\%, m.p: $192{ }^{\circ} \mathrm{C}$ decomp. ${ }^{1} \mathrm{H}-\mathrm{NMR} \delta: 2.33(3 \mathrm{H}, \mathrm{s}), 4.55(2 \mathrm{H}, \mathrm{s}), 7.15(1 \mathrm{H}, \mathrm{d}, J=3.6), 7.42$ $(2 \mathrm{H}, \mathrm{d}, J=8.1), 7.54(1 \mathrm{H}, \mathrm{d}, J=3.6), 7.77(2 \mathrm{H}, \mathrm{d}, J=8.1), 11.50$ (1H, br s, $\mathrm{D}_{2} \mathrm{O}$ exchangeable). IR $\mathrm{cm}^{-1}$ : 3441, br $(\mathrm{NH}), 3089(\mathrm{CH}$ aromatic), $2912(\mathrm{CH}$ aliphatic), $2218(\mathrm{C} \equiv \mathrm{N}), 1693$ and $1658(\mathrm{C}=\mathrm{Os})$. Anal. Calcd. for $\mathrm{C}_{18} \mathrm{H}_{12} \mathrm{BrN}_{3} \mathrm{O}_{3} \mathrm{~S}$ (430.28): C, 50.25; H, 2.81; N, 9.77. Found: C, 50.18; H, 2.76; N, 9.97. MS $m / z: 429[\mathrm{M}]^{+}, 431[\mathrm{M}+2]^{+}$.

2-(4-Bromobenzoylmethylthio)-6-(5-methylthiophen-2-yl)-4-oxo-3,4-dihydropyrimidine-5-carbonitrile (6i): Yield 45\%, m.p: $196-198{ }^{\circ} \mathrm{C} .{ }^{1} \mathrm{H}-\mathrm{NMR} \delta: 2.37(3 \mathrm{H}, \mathrm{s}), 4.51(2 \mathrm{H}, \mathrm{s}), 6.88(1 \mathrm{H}, \mathrm{d}, J=3.9), 7.39$ $(2 \mathrm{H}, \mathrm{d}, J=8.1), 7.69(1 \mathrm{H}, \mathrm{d}, J=3.9), 7.97(2 \mathrm{H}, \mathrm{d}, J=8.1), 11.40\left(1 \mathrm{H}\right.$, br s, $\mathrm{D}_{2} \mathrm{O}$ exchangeable). IR cm ${ }^{-1}: 3421$, br $(\mathrm{NH}), 3043(\mathrm{CH}$ aromatic), $2916(\mathrm{CH}$ aliphatic), $2210(\mathrm{C} \equiv \mathrm{N}), 1700$ and 1616 $(\mathrm{C}=\mathrm{Os})$. Anal. Calcd. for $\mathrm{C}_{18} \mathrm{H}_{12} \mathrm{BrN}_{3} \mathrm{O}_{2} \mathrm{~S}_{2}$ (446.34): C, 48.44; H, 2.71; N, 9.41. Found: $\mathrm{C}, 48.43$; $\mathrm{H}$, $2.61 ; \mathrm{N}, 9.73$. MS $m / z: 445[\mathrm{M}]^{+}, 447[\mathrm{M}+2]^{+}$.

6-Aryl-5-cyano-4-oxo-3,4-dihydropyrimidin-2-yl

2-(4-bromophenyl)-N'-(4-hydroxyphenyl)-2-oxoethanehydrazonothioates $\mathbf{7 a - c}$. An ice cold diazonium salt solution of $p$-aminophenol (prepared from $p$-aminophenol $(1.09 \mathrm{~g}, 0.01 \mathrm{~mol})$, glacial acetic acid $(4 \mathrm{~mL})$ and sodium nitrite $(0.69 \mathrm{~g}$, $0.01 \mathrm{~mol})$ in water $(15 \mathrm{~mL}))$ was added to a chilled solution of the appropriate 6-Aryl-2-(4bromobenzoylmethylthio)-4-oxo-3,4-dihydropyrimidine-5-carbonitrile $6 \mathbf{6}, 6 \mathbf{6}$ or $6 \mathbf{6 e}(0.01 \mathrm{~mol})$ and sodium hydroxide $(1.6 \mathrm{~g}, 0.04 \mathrm{~mol})$ in water $(25 \mathrm{~mL})$. The reaction mixture was maintained at $-5{ }^{\circ} \mathrm{C}$ with continuous stirring for $30 \mathrm{~min}$, and then acidified with glacial acetic acid till $\mathrm{pH}$ 5-5.5. The resulting solid was filtered, washed twice with water, dried and crystallized from methanol.

5-Cyano-4-oxo-6-phenyl-3,4-dihydropyrimidin-2-yl 2-(4-bromophenyl)- $N$ '-(4-hydroxyphenyl)-2-oxoethanehydrazonothioate (7a): Yield 65\%, m.p: $188-190{ }^{\circ} \mathrm{C} .{ }^{1} \mathrm{H}-\mathrm{NMR} \delta: 6.86(2 \mathrm{H}, \mathrm{d}, J=8.4), 7.43$ $(2 \mathrm{H}, \mathrm{d}, J=6.9), 7.54-7.64(5 \mathrm{H}, \mathrm{m}), 7.66(4 \mathrm{H}, \mathrm{d}, J=8.1), 10.11\left(1 \mathrm{H}\right.$, br s, $\mathrm{D}_{2} \mathrm{O}$ exchangeable $), 11.85$ $\left(1 \mathrm{H}, \mathrm{s}, \mathrm{D}_{2} \mathrm{O}\right.$ exchangeable), $13.20\left(1 \mathrm{H}, \mathrm{s}, \mathrm{D}_{2} \mathrm{O}\right.$ exchangeable). IR $\mathrm{cm}^{-1}: 3417-3252$ ( $\mathrm{NH}$ and $\left.\mathrm{OH}\right)$, $3086\left(\mathrm{CH}\right.$ aromatic), $2210(\mathrm{C} \equiv \mathrm{N}), 1660$ and $1640(\mathrm{C}=\mathrm{Os})$. Anal. Calcd. for $\mathrm{C}_{25} \mathrm{H}_{16} \mathrm{BrN}_{5} \mathrm{O}_{3} \mathrm{~S}(546.40)$ : C, 54.95; H, 2.95; N, 12.82. Found: C, 54.93; H, 3.03; N, 12.97. MS m/z: $547[\mathrm{M}+2]^{+}, 549[\mathrm{M}+4]^{+}$. 
6-(4-Bromophenyl)-5-cyano-4-oxo-3,4-dihydropyrimidin-2-yl 2-(4-bromophenyl)-N'-(4-hydroxyphenyl)2-oxoethanehydrazonothioate (7b): Yield 60\%, m.p: $240{ }^{\circ} \mathrm{C}$ decompose. ${ }^{1} \mathrm{H}-\mathrm{NMR} \delta: 7.41(2 \mathrm{H}, \mathrm{d}, J=8.4)$, 7.63-7.75 (8H, m), $7.92(2 \mathrm{H}, \mathrm{d}, J=8.7), 10.00\left(1 \mathrm{H}\right.$, br s, $\mathrm{D}_{2} \mathrm{O}$ exchangeable $), 10.70\left(1 \mathrm{H}, \mathrm{br}, \mathrm{D}_{2} \mathrm{O}\right.$ exchangeable), $11.85\left(1 \mathrm{H}, \mathrm{s}, \mathrm{D}_{2} \mathrm{O}\right.$ exchangeable). IR $\mathrm{cm}^{-1}: 3417-3300(\mathrm{NH}$ and $\mathrm{OH}), 3089(\mathrm{CH}$ aromatic), $2214(\mathrm{C} \equiv \mathrm{N}), 1670(\mathrm{C}=\mathrm{O}), 1654(\mathrm{C}=\mathrm{O})$. Anal. Calcd. for $\mathrm{C}_{25} \mathrm{H}_{15} \mathrm{Br}_{2} \mathrm{~N}_{5} \mathrm{O}_{3} \mathrm{~S}$ (625.29): $\mathrm{C}$, 48.02; H, 2.42; N, 11.20. Found: C, 48.11; H, 2.45; N, 11.37. MS m/z: $623[\mathrm{M}]^{+}, 625[\mathrm{M}+2]^{+}$.

Cyano-4-oxo-6-p-tolyl-3,4-dihydropyrimidin-2-yl 2-(4-bromophenyl)- $N$-(4-hydroxyphenyl)-2-oxoethanehydrazonothioate (7c): Yield 58\%, m.p: $231{ }^{\circ} \mathrm{C}$ decompose. ${ }^{1} \mathrm{H}-\mathrm{NMR} \delta: 2.32(3 \mathrm{H}, \mathrm{s}), 7.07(2 \mathrm{H}$, $\mathrm{d}, J=8.1), 7.34(2 \mathrm{H}, \mathrm{d}, J=8.4), 7.51(2 \mathrm{H}, \mathrm{d}, J=8.1), 7.72(2 \mathrm{H}, \mathrm{d}, J=8.7), 7.85$ (2H, d, $J=8.4), 7.92$ $(2 \mathrm{H}, \mathrm{d}, J=8.7), 9.41(1 \mathrm{H}, \mathrm{br}), 10.05(1 \mathrm{H}, \mathrm{s}), 11.80(1 \mathrm{H}, \mathrm{s}) .{ }^{13} \mathrm{C}-\mathrm{NMR} \delta: 21.01,92.45,115.79$, $127.82,128.42,128.72,129.12,130.23,131.23,131.64,131.74,131.80,134.52,134.81,141.85$, 161.04, 165.03, 166.81, 192.15. IR cm ${ }^{-1}: 3417-3124(\mathrm{NH}$ and $\mathrm{OH}), 3066(\mathrm{CH}$ aromatic), $2214(\mathrm{C} \equiv \mathrm{N})$, $1660(\mathrm{C}=\mathrm{O}), 1632(\mathrm{C}=\mathrm{O})$. Anal. Calcd. for $\mathrm{C}_{26} \mathrm{H}_{18} \mathrm{BrN}_{5} \mathrm{O}_{3} \mathrm{~S}$ (560.42): C, 55.72; H, 3.24; N, 12.50 . Found: C, 55.78; H, 3.31; N, 12.66. MS m/z: $561[\mathrm{M}+2]^{+}$.

2-(4-Bromobenzoyl)-5-(4-bromophenyl)-7-oxo-7H-thiazolo[3,2-a]pyrimidine-6-carbonitrile 9. A mixture of 6-(4-bromophenyl)-2-(4-bromobenzoylmethylthio)-4-oxo-3,4-dihydropyrimidine-5-carbonitrile $\mathbf{6 c}$ $(0.01 \mathrm{~mol})$ and triethyl orthoformate $(1.48 \mathrm{~g}, 1.3 \mathrm{~mL}, 0.01 \mathrm{~mol})$ in acetic anhydride $(10 \mathrm{~mL})$ was heated under reflux with stirring for $8 \mathrm{~h}$. The solvent was concentrated under reduced pressure and the reaction mixture was left overnight. The formed solid was collected, dried and crystallized from aqueous methanol. Yield 40\%, m.p: $170-172{ }^{\circ} \mathrm{C} .{ }^{1} \mathrm{H}-\mathrm{NMR} \delta: 7.60(4 \mathrm{H}, \mathrm{d}, J=8.4), 7.65(1 \mathrm{H}, \mathrm{s}), 7.82$ $(4 \mathrm{H}, \mathrm{d}, J=8.4) . \mathrm{IR} \mathrm{cm}^{-1}: 3086(\mathrm{CH}$ aromatic), $2210(\mathrm{C} \equiv \mathrm{N}), 1660(\mathrm{C}=\mathrm{O}), 1640(\mathrm{C}=\mathrm{O})$. Anal. Calcd. for $\mathrm{C}_{20} \mathrm{H}_{9} \mathrm{Br}_{2} \mathrm{~N}_{3} \mathrm{O}_{2} \mathrm{~S}$ (515.18): C, 46.63; H, 1.76; N, 8.16. Found: C, 46.71; H, 1.82; N, 8.28. MS m/z: $513[\mathrm{M}]^{+}, 515[\mathrm{M}+2]^{+}$.

\subsection{Biological Evaluation}

\subsubsection{Determination of the Antimicrobial Activitiess}

The antimicrobial activity expressed as $\mathrm{MIC}, \mathrm{MBC}$ and $\mathrm{IC}_{50}$ of tested compounds were determined against four reference bacterial strains; Staphylococcus aureus ATCC 6538P, Bacillus subtilis ATCC CC33, Escherichia coli ATCC 5087, Pseudomonas aeruginosa ATCC 9027 as well as against two fungi strains; Candida albicans ATCC 60193 and Aspergillus niger ATCC 1718109. Amoxicillin, gentamicin and amphotericin B were used as positive control. All assays were conducted in triplicate under strict aseptic conditions.

\subsubsection{Determination of the Minimum Inhibitory Concentration (MIC)}

The preliminary MICs were firstly determined by the microbroth dilution method [30]. Briefly, $100 \mu \mathrm{L}$ of double strength DMSO (Sigma-Aldrich, Munich, Germany) were placed in each well of a 96-well microtiter plate. Aliquot of $100 \mu \mathrm{L}$ of the solutions to be tested were added to the first column. Then 2-fold dilutions were carried out from one well to the next up to final well in each row for each tested compound. 
MICs were then determined using agar streaking technique as per Clinical Laboratory Standard Institute guidelines [30]. A total of $15 \mathrm{~mL}$ molten $\left(45^{\circ} \mathrm{C}\right)$ Neutrient agar (Sigma-Aldrich) were supplemented with the required concentration then were added into sterilized Petri dishes, allowed to solidify. Then $10 \mu \mathrm{L}$ of each bacterial or fungal suspension $\left(10^{5} \mathrm{CFU} \mathrm{mL}^{-1}\right)$ were streaked onto the surface. Finally all plates were incubated at $37{ }^{\circ} \mathrm{C}$ for $24 \mathrm{~h}$ for bacterial strains and $25{ }^{\circ} \mathrm{C}$ for $48 \mathrm{~h}$ fungal strains under aerobic conditions. MIC was determined as the average between the last plate had growth and the first plate with no growth.

\subsubsection{Determination of the $\mathrm{MBC}$ and $\mathrm{IC}_{50}$}

$\mathrm{MBC}$ and $\mathrm{IC}_{50}$ were determined in 96 well microtiter plate where a $100 \mu \mathrm{L}$ of trypcase soya broth (Oxoid, Lenexa, KS, USA) for bacterial isolates or sabaroud's dextrose broth for fungal strains were placed in each well. A proper amount of the stock solution of the tested compounds was added to reach the desired concentration. All columns were then inoculated with $20 \mu \mathrm{L}$ of bacterial suspension $\left(10^{6} \mathrm{CFU} \mathrm{mL} \mathrm{mL}^{-1}\right)$ and incubated for 5-6 h. An aliquot of $100 \mu \mathrm{L}$ from each well was transferred into another pre-supplemented with $100 \mu \mathrm{L}$ f Dey-engly broth medium (Fluka, St. Louis, MO, USA) and allowed to stand for 10-20 min to neutralized any antimicrobial activities. Then these neutralized solutions were subjected to proper dilutions and streaked onto trypcase soya agar or sabaroud's dextrose agar plates to determine the viable count [41]. Controls were done for sterility and growth and subjected to the same regimen of treatment. MBC was determined as the lowest concentration which decreased the number of viable bacteria by $3 \mathrm{log}$ units. $\mathrm{IC}_{50}$ was determined as the lowest concentration reduced the viable count by about $50 \%$.

\subsubsection{Anticancer Activity [37]}

The human tumor cell lines of the cancer screening panel are grown in RPMI 1640 medium containing 5\% fetal bovine serum and $2 \mathrm{mM}$ L-glutamine. For a typical screening experiment, cells are inoculated into 96 well microtiter plates in $100 \mu \mathrm{L}$ at plating densities ranging from 5,000 to 40,000 cells/well depending on the doubling time of individual cell lines. After cell inoculation, the microtiter plates are incubated at $37{ }^{\circ} \mathrm{C}, 5 \% \mathrm{CO}_{2}, 95 \%$ air and $100 \%$ relative humidity for $24 \mathrm{~h}$ prior to addition of experimental drugs. After $24 \mathrm{~h}$, two plates of each cell line are fixed in situ with trichloroacetic acid (TCA), to represent a measurement of the cell population for each cell line at the time of drug addition (Tz). Experimental drugs are solubilized in dimethyl sulfoxide at 400 -fold the desired final maximum test concentration and stored frozen prior to use. At the time of drug addition, an aliquot of frozen concentrate is thawed and diluted to twice the desired final maximum test concentration with complete medium containing $50 \mu \mathrm{g} / \mathrm{mL}$ gentamicin. Aliquots of $100 \mu \mathrm{L}$ of the compound dilution is added to the appropriate microtiter wells already containing $100 \mu \mathrm{L}$ of medium, resulting in the required final compound concentrations. Following compound addition, the plates are incubated for an additional $48 \mathrm{~h}$ at $37{ }^{\circ} \mathrm{C}, 5 \% \mathrm{CO}_{2}, 95 \%$ air, and $100 \%$ relative humidity. For adherent cells, the assay is terminated by the addition of cold TCA. Cells are fixed in situ by the gentle addition of $50 \mu \mathrm{L}$ of cold $50 \%(\mathrm{w} / \mathrm{v})$ TCA (final concentration, 10\% TCA) and incubated for $60 \mathrm{~min}$ at $4{ }^{\circ} \mathrm{C}$. The supernatant is discarded, and the plates are washed five times with tap water and air dried. Sulforhodamine B (SRB) solution $(100 \mu \mathrm{L})$ at $0.4 \%(\mathrm{w} / \mathrm{v})$ in $1 \%$ acetic acid is added to each well, and plates are incubated for 10 minutes 
at room temperature. After staining, unbound dye is removed by washing five times with $1 \%$ acetic acid and the plates are air dried. Bound stain is subsequently solubilized with $10 \mathrm{mM}$ trizma base, and the absorbance is read on an automated plate reader at a wavelength of $515 \mathrm{~nm}$. For suspension cells, the methodology is the same except that the assay is terminated by fixing settled cells at the bottom of the wells by gently adding $50 \mu \mathrm{L}$ of $80 \%$ TCA (final concentration, 16\% TCA). Using the seven absorbance measurements [time zero, $(\mathrm{Tz})$, control growth, $(\mathrm{C})$, and test growth in the presence of drug at the five concentration levels (Ti)], the percentage growth is calculated at each of the drug concentrations levels. Percentage growth inhibition is calculated as: $[(\mathrm{Ti}-\mathrm{Tz}) /(\mathrm{C}-\mathrm{Tz})] \times 100$ for concentrations for which $\mathrm{Ti}>/=\mathrm{Tz}$ or $[(\mathrm{Ti}-\mathrm{Tz}) / \mathrm{Tz}] \times 100$ for concentrations for which $\mathrm{Ti}<\mathrm{Tz}$.

\section{Conclusions}

This study reports the synthesis of 6-aryl-5-cyanothiouracil based compounds $4 \mathbf{a}-\mathbf{i}, \mathbf{6 a}-\mathbf{i}, 7 \mathbf{a}-\mathbf{c}$ and 9 as potential antimicrobial and antitumor agents. Several newly synthesized derivatives displayed promising antimicrobial activity compared to the reference drugs, amoxicillin, gentamicin and amphotericin B. The activity against gram positive bacteria $S$. aureus and to a lesser extent $B$. subtilis was a characteristic of the majority of active compounds. It can be stated that final compounds $\mathbf{6} \mathbf{f}$ and 6g with mesomeric electron donating methoxy substituents on the phenyl at the 6 position of the thiouracil scaffold were found more active than the other analogs against both Gram positive strains. In addition, the introduction of 4-hydroxyphenylhdrazono moiety in $\mathbf{7 b}$ and $\mathbf{7} \mathbf{c}$ contributed to excellent potency toward the same bacterial strains. On the other hand, in vitro cytotoxicity screening of selected compounds $4 \mathbf{d}, 4 \mathbf{g}-\mathbf{i}$ and $6 \mathbf{a}-\mathbf{i}$ at a single concentration of $10^{-5} \mathrm{M}$-revealed that most of the compounds had limited cytotoxic activity against renal cancer UO-31 or A498 cell lines. However, compounds 6d and 6i exhibited potent growth inhibitory effect toward non-small cell lung cancer HOP-92 and leukemia MOLT-4 cell lines, respectively.

\section{Acknowledgments}

The authors are grateful to the staff members of Biotechnology Center, Faculty of Pharmacy, Cairo University for running the antimicrobial screening. The authors would like to express their sincere thanks to the NCI staff, Bethesda, MD, USA for performing the antitumor testing of the synthesized compounds.

\section{References}

1. Maga, G.; Radi, M.; Gerard, M.A.; Botta, M.; Ennifar, E. HIV-1 RT inhibitors with novel mechanism of action: NNRTIs that compete with the nucleotide substrate. Viruses 2010, 2, 880-899.

2 Callery, P.; Gannett, P. Cancer and cancer chemotherapy. In Foye's Principles of Medicinal Chemistry, 5th ed.; Williams, D.A., Lemke, T.L., Eds.; Lippincot Williams and Wilkins: Philadelphia, PA, USA, 2002; pp. 934-935.

3. Deshmukh, M.B.; Salunkhe, S.M.; Patil, D.R.; Anbhule, P.V. A novel and efficient one step synthesis of 2-amino-5-cyano-6-hydroxy-4-aryl pyrimidines and their anti-bacterial activity. Eur. J. Med. Chem. 2009, 44, 2651-2654. 
4. Masoud, M.S.; Ibrahim, A.A.; Khalil, E.A.; El-Marghany, A. Spectral properties of some metal complexes derived from uracil-thiouracil and citrazinic acid compounds. Spectrochim Acta A Mol. Biomol. Spectrosc. 2007, 67, 662-668.

5. Fathalla, O.A.; Awad, S.M.; Mohamed, M.S. Synthesis of new 2-thiouracil-5-sulfonamide derivatives with antibacterial and antifungal activity. Arch. Pharm. Res. 2005, 28, 1205-1212.

6. Odani, A.; Kozlowski, H.; Swiatek-Kozlowska, J.; Brasun, J.; Operschall, B.P.; Sigel, H. Extent of metal ion-sulfur binding in complexes of thiouracil nucleosides and nucleotides in aqueous solution. J. Inorg. Biochem. 2007, 101, 727-735.

7. Prachayasittikul, S.; Sornsongkhram, N.; Pingaew, R.; Techatanachai, S.; Ruchirawat, S.; Prachayasittikul, V. Synthesis and novel bioactivities of substituted 6-propylthiouracils. Eur. J. Sci. Res. 2009, 36, 236-245.

8. Prachayasittikul, S.; Worachartcheewan, A.; Nantasenamat, C.; Chinworrungsee, M.; Sornsongkhram, N.; Ruchirawat, S.; Prachayasittikul, V. Synthesis and structure-activity relationship of 2-thiopyrimidine-4-one analogues as antimicrobial and anticancer agents. Eur. J. Med. Chem. 2011, 46, 738-742.

9. He, Y.P.; Long, J.; Zhang, S.S.; Li, C.; Lai, C.C.; Zhang, C.S.; Li, D.X.; Zhang, D.H.; Wanga, H.; Cai, Q.Q.; Zheng, Y.T. Synthesis and biological evaluation of novel dihydro-aryl/alkylsulfanylcyclohexylmethyl-oxopyrimidines (S-DACOs) as high active anti-HIV agents. Bioorg. Med. Chem. Lett. 2011, 21, 694-697.

10. He, Y.; Chen, F.; Sun, G.; Wang, Y.; Clercq, E.D.; Balzarini, J.; Pannecouque, C. Alkyl-2-[(aryl and alkyloxylcarbonylmethyl)thio]-6-(1-naphthylmethyl)pyrimidin-4(3H)-ones as an unique HIV reverse transcriptase inhibitors of S-DABO series. Bioorg. Med. Chem. Lett. 2004, 14, 3173-3176.

11. Abdel-Mohsen, H.T.; Ragab, F.AF.; Ramala, M.M.; El-Diwani, H.I. Novel benzimidazolepyrimidine conjugates as potent antitumor agents. Eur. J. Med. Chem. 2010, 45, 2336-2344.

12. Galal, S.A.; Abdelsamie, A.S.; Tokuda, H.; Suzuki, N.; Lida, A.; El-Hefnawi, M.M.; Ramadan, R.A.; Atta, M.H.E.; El Diwani, H.I. Part I: Synthesis, cancer chemopreventive activity and molecular docking study of novel quinoxaline derivatives. Eur. J. Med. Chem. 2011, 46, $327-340$.

13. Al-Abdullah, E.S.; Al-Obaid, A.-R.M.; Al-Deeb, O.A.; Habib, E.E.; El-Emam, A.A. Synthesis of novel 6-phenyl-2,4-disubstituted pyrimidine-5-carbonitriles as potential antimicrobial agents. Eur. J. Med. Chem. 2011, 46, 4642-4647.

14. Mohamed, M.S.; Awad, S.M.; Ahmed, N.M. Anticancer cancer activities of 6-aryl-5-cyano-2thiouracil derivatives. Pharma Res. 2012, 6, 54-60.

15. Mohamed, M.S.; Awad, S.M.; Ahmed, N.M. Synthesis and antimicrobial evaluation of some 6-aryl-5-cyano-2-thiouracil derivatives. Acta Pharm. 2011, 61, 171-185.

16. Fathalla, O.A.; Zeid, I.F.; Haiba, M.E.; Soliman, A.M. Synthesis, antibacterial and anticancer evaluation of some pyrimidine derivatives. World J. Chem. 2009, 4, 127-132.

17. Chen, W.; Huang, Y.; Gundala, S.R.; Yan, H.; Li, M.; Tai, P.C.; Wang, B. The first low $\mu$ M SecA inhibitors. Bioorg. Med. Chem. 2010, 18, 1617-1625.

18. Ding, Y.; Girardet, J.L.; Smith, K.L.; Larson, G.; Prigaro, B.; Wu, J.Z.; Yao, N. Parallel synthesis of 5-cyano-6-aryl-2-thiouracil derivatives as inhibitors for hepatitis C viral NS5B RNA-dependent RNA polymerase. Bioorg. Chem. 2006, 34, 26-38. 
19. Chen, H.; Tsalkova, T.; Mei, F.C.; Hu, Y.; Cheng, X.; Zhou, J. 5-Cyano-6-oxo-1,6-dihydropyrimidines as potent antagonists targeting exchange proteins directly activated by cAMP. Bioorg. Med. Chem. Lett. 2012, 22, 4038-4043.

20. Rose, Y.; Ciblat, S.; Reddy, R.; Belley, A.; Dietrich, L.; McKay, G.; Rafai, A.; Delorme, D. Novel non-nucleobase inhibitors of Staphylococcus aureus DNA polymerase IIIC. Bioorg. Med. Chem. Lett. 2006, 16, 891-896.

21. Onnis, V.; Cocco, M.T.; Fadda, R.; Congiu, C. Synthesis and evaluation of anticancer activity of 2-arylamino-6-trifluoromethyl-3-(hydrazonocarbonyl)pyridines. Bioorg. Med. Chem. 2009, 17, $6158-6165$.

22. Edrees, M.M.; Farghaly, T.A.; El-Hag, F.A.A.; Abdalla, M.M. Antimicrobial, antitumor and $5 \alpha$-reductase inhibitor activities of some hydrazonoyl substituted pyrimidinones. Eur. J. Med. Chem. 2010, 45, 5702-5707.

23. Shawali, A.S.; Elghandour, A.H.; Sayed, A.R. A Novel One-Pot Synthesis of 3-arylazo[1,2,4]triazolo[4,3-a]pyrimidin-5(1H)-ones. Synth. Commun. 2001, 31, 731-740.

24. Bedford, G.R.; Taylor, P.J.; Webb, G.A. ${ }^{15} \mathrm{~N}-\mathrm{NMR}$ studies of guanidines. II-the fused-in guanidine unit of some oxoheterocycles: A combined ${ }^{15} \mathrm{~N}-\mathrm{NMR},{ }^{13} \mathrm{C}-\mathrm{NMR}$ and IR study. Magn. Res. Chem. 1995, 33, 389-394.

25. Elguero, J.; Goya, P.; Martinez, A.; Rozas, I. On the tautomerism of 2-phenacyl-4-pyrimidinones and related compounds. Chem. Ber. 1989, 122, 919-924.

26. Greenhill, J.V.; Ismail, M.J.; Bedford, G.R.; Edwards, P.N.; Taylor, P.J.J. Conformational and tautomeric studies of acylguanidines. II: Vibrational and carbon-13 nuclear magnetic resonance spectroscopy. Chem. Soc. Perkin Trans. 1985, 2, 1265-1274.

27. Reiter, J.; Bongo, L.; Dyortsok, P. Synthesis and tautomeric structure of 2-[N-aryl-2-oxo-2arylethanehydrazonoyl]-6-methyl-4(3H)-pyrimidinones. Tetrahedron 1987, 43, 2497-2504.

28. Jones, R.; Rayan, A.J.; Sternhell, S.; Wright, S.E. The structures of some 5-pyrazolones and derived 4-arylazo-5-pyrazolones. Tetrahedron 1963, 19, 1497-1507.

29. Shawali, A.S.; Farghaly, T.A. Synthesis and tautomeric structure of 2-[N-aryl-2-oxo-2arylethanehydrazonyl]-6-methyl-4(3H)-pyrimidinone. Tetrahedron 2004, 60, 3051-3057.

30. Clinical and Laboratory Standards Institute (CLSI). Performance Standards for Antimicrobial Susceptibility Testing, 19th Informational Supplement; CLSI: Wayne, PA, USA, 2009.

31. Nostro, A.; Roccaro, A.S.; Bisignano, G.; Marino, A.; Cannatelli, M.A.; Pizzimenti, F.C.; Cioni, P.L.; Procopio, F.; Blanco, A.R. Effects of oregano, Carvacrol and thymol on Staphylococcus aureus and Staphylococcus epidermidis biofilms. Med. Microbiol. 2007, 56, 519-523.

32. Prindle, R.F.; Wright, E.S. Phenolic compounds. In Disinfection, Sterilization and Preservation; Block S.S., Ed.; Lea and Febiger: Philadelfia, PA, USA, 1997; pp. 115-118.

33. Juven, B.J.; Kanner, J.; Schved, F.; Weisslowicz, H. Factors that interact with the antibacterial action of thyme essential oil and its active constituents. J. Appl. Bacteriol. 1994, 76, 626-631.

34. Monks, A.; Scudiero, D.; Skehan, P.; Shoemaker, R.; Paull, K.; Vistica, D.; Hose, C.; Langley, J.; Cronise, P.; Vaigro-Wolfe, A.; et al. Feasibility of a high-flux anticancer drug screen utilizing a diverse panel of human tumor cell lines in culture. J. Natl. Cancer Inst. 1991, 83, 757-766.

35. Boyd, M.R.; Paull, K.D. Some practical considerations and applications of the National Cancer Institute in vitro anticancer drug discovery screen. Drug Dev. Res. 1995, 34, 91-109. 
36. Boyd, M.R. Cancer Drug Discovery and Development. In Anticancer Drug Development Guide: Preclinical Screening, Clinical Trials and Approval; Teicher B.A., Ed.; Humana Press: Totowa, NJ, USA, 1997; Volume 2, pp. 23-43.

37. Skehan, P.; Storeng, R.; Scudiero, D.; Monks, A.; McMahon, J.; Vistica, D.; Warren, J.; Bokesch, H.; Kenney, S.; Boyd, M. New colorimetric cytotoxicity assay for anticancer-drug screening. J. Natl. Cancer Inst. 1990, 82, 1107-1112.

38. Parmar, J.M.; Modha, J.J.; Parikh, A.R. Synthesis of azetidinones and thiazolidinones from hydrazinopyrimidine as potential antimicrobial agents. Indian J. Chem. 1999, 38, 440-444.

39. Khodair, A.I.; Ibrahim, E.E.; Ashry, E.S.H. Glycosylation of 2-thiouracil derivatives. A synthetic approach to 3-glycosyl-2,4-dioxypyrimidines. Nucleosides Nucleotides 1997, 16, 433-444.

40. Abdou, I.B.; Strekowski, L. A facile synthesis of 6-aryl-5-cyano-1-( $\beta$-d-pyranosyl or $\beta$-d-furanosyl)-2-thiocytosines. Tetrahedron 2000, 56, 8631-8636.

41. Azéma, J.; Guidetti, B.; Korolyov, A.; Kiss, R.; Roques, C.; Constant, P.; Daffé, M.; Malet-Martino, M. Synthesis of lipophilic dimeric C-7/C-7-linked ciprofloxacin and C-6/C-6-linked levofloxacin derivatives. Versatile in vitro biological evaluations of monomeric and dimeric fluoroquinolone derivatives as potential antitumor, antibacterial or antimycobacterial agents. Eur. J. Med. Chem. 2011, 46, 6025-6038.

Sample Availability: Samples of the compounds $\mathbf{6 a}-\mathbf{i}, 7 \mathbf{7}-\mathbf{c}$ are available from the authors.

(C) 2012 by the authors; licensee MDPI, Basel, Switzerland. This article is an open access article distributed under the terms and conditions of the Creative Commons Attribution license (http://creativecommons.org/licenses/by/3.0/). 